\title{
Nutritive value of cereal and cassava diets for growing and fattening pigs in Nigeria
}

\author{
By V. A. OYENUGA \\ Subdepartment of Agricultural Chemistry, Faculty of Agriculture, \\ University College, Ibadan \\ (Received I2 September 1960-Revised 20 Fanuary 1961)
}

In a previous report (Oyenuga \& Opeke, 1957) the nutritional and economic importance, real and potential, of cassava root (Manihot utilissima Pohl) to man and in livestock production in Nigeria was stressed. Cassava is not only the most widely grown vegetable in Nigeria (it accounted for nearly $50 \%$ of the total root crops produced in the country in $195^{\circ}-1$ ), it is also the most productive farm crop, yielding edible nutrients equivalent to an average of over $\mathrm{I} 3 \mathrm{million} \mathrm{kcal} / \mathrm{acre}$ compared with 9 million from yam (Dioscorea sp.), I million from guinea corn (Sorghum vulgare Pers.) and I million from maize (Zea mays L.). It is therefore the cheapest source of calories for man and livestock in the country.

Information on the chemical constituents of cassava root is scanty. Its nutritive value and the availability and metabolic usefulness to farm animals of its more important chemical constituents are little known. It would appear that qualitative and quantitative studies of some of its more important chemical constituents and of the requirements of the animal body for them would contribute to a clearer appraisal of its nutritive value for livestock.

In the experiments reported now the nutritive value for pigs of raw and boiled cassava roots was compared and, in the first experiment, both forms of cassava were compared with a standard guinea-corn diet. In the second experiment the metabolism of nitrogen, calcium and phosphorus in growing pigs fed on raw or boiled cassava was studied. The second experiment also compared the effect of the simple mineral mixture hitherto included in diets used in this Department with a commercial I.C.I. iodized mineral mixture.

\section{EXPERIMENTAL}

\section{Animals}

Home-bred, tri-hybrid pigs from Large Black, Tamworth and Large White breeds were used. In Expt I nine pigs (six male and three female) were divided into three groups carefully selected on the basis of litter origin, live weight and sex; particulars are given in Table $\mathrm{x}$. In Expt 2, in which balances of $\mathrm{N}, \mathrm{Ca}$ and $\mathrm{P}$ were estimated, four pigs were used, whose particulars are also given in Table I. 


\section{Metabolic cages}

In both experiments the animals were kept and fed individually in wooden metabolic cages (Pls. I, 2). Each cage, designed by me, is $5 \mathrm{ft} 6$ in. long, $3 \mathrm{ft}$ wide and $4 \mathrm{ft}$ high, and is raised on wooden pillars about 9 in. from the ground. It is made of wooden frames surrounded on all sides by expanded metal mesh, 3 in ${ }^{2}$, permitting the good circulation of air essential in this tropical environment. The door of the cage opens on one side, enabling the pig to go in and out when required; on the side opposite to the door is a wooden trough for food and on the left side another for drinking-water. Both troughs can be opened from outside the cage for filling and cleaning and are so constructed as to reduce to a minimum scattering of food and splashing of water when the pig is eating or drinking. All parts of the cage accessible to the pig, including the troughs, are lined with aluminium sheeting to prevent the pigs from biting the wood.

Table I. Expts I and 2. Sex, ages and weights of the pigs at the beginning of the experiments

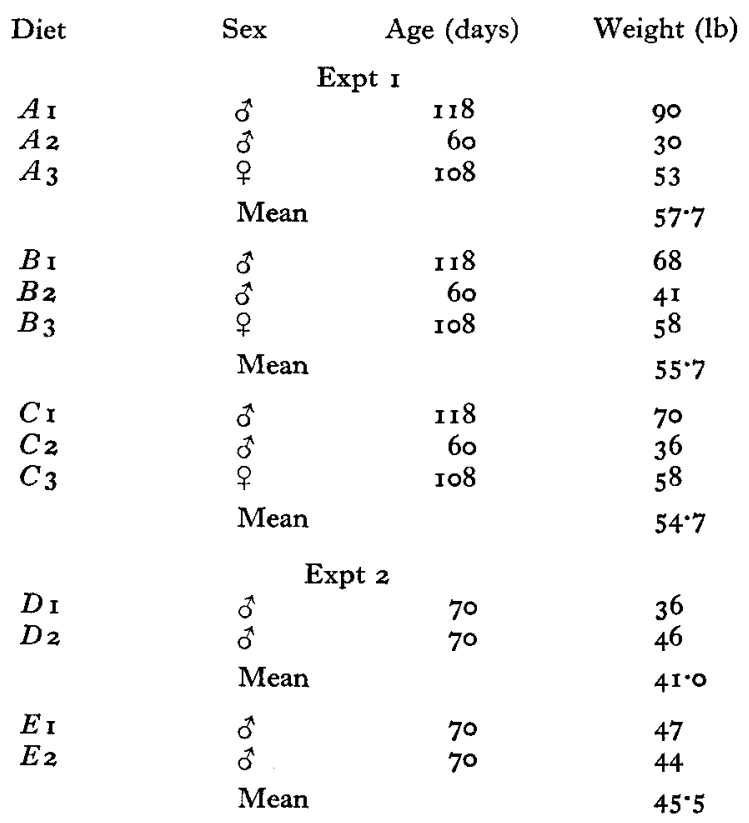

The floor of the cage consists of two removable trays of closely knit wire mesh reinforced with strong expanded metal grid. They can be withdrawn for collection of faeces and for cleaning, and replaced at will. This floor retains effectively all faecal matter but permits the urine to drain freely on to the aluminium tray below. The latter is sloped so as to allow easy drainage to its funnel-shaped tube at the centre. The tube is connected by rubber tubing through a hole bored in the lid of a closed bucket in which the urine collects. The compact, solid cage is large enough to house a pig 
weighing up to about $300 \mathrm{lb}$ and at the same time light enough to be moved from place to place.

The cages were housed in a shed with a concrete floor and walls $3 \mathrm{ft}$ high. The aluminium roof was raised $\mathrm{r} 2 \mathrm{ft}$ above the floor and the whole shed was open and cool. It was surrounded with ditches filled with water to prevent ants and snakes from entering it. For Pls. I and 2 the cages were photographed outside the shed.

\section{Diets, feeding and management}

Particulars of diets $A, B$ and $C$ used in Expt $\mathbf{I}$ are given in Table 2. The cassava for diet $B$ was boiled, that for diet $C$ was unboiled. On the wet-weight basis, three times as much cassava as guinea corn was used to equate their dry-matter contents. The blood-meal mixture, which was the only source of animal protein, consisted of equal parts of abattoir blood and coarse rice bran, the protein content being $34 \%$ (Oyenuga, I955). The mineral mixture consisted of: crushed oyster shell $5 \circ$, crushed bone 25 and common salt $(\mathrm{NaCl}) 25 \%$.

Table 2. Expt I. Proportions in which the ingredients of the diets $(A)$ containing guinea corn, $(B)$ containing boiled cassava and $(C)$ containing raw cassava were mixed

(All values on dry-matter basis)

\begin{tabular}{|c|c|c|c|c|c|c|}
\hline \multirow[b]{2}{*}{ Ingredient } & \multicolumn{3}{|c|}{ Period I, porkers } & \multicolumn{3}{|c|}{ Period 2, baconers } \\
\hline & $A$ & $B$ & $C$ & $A$ & $B$ & $C$ \\
\hline Guinea corn & 52 & - & - & 80 & - & 一 \\
\hline Cassava root & - & 52 & 52 & - & 55 & 55 \\
\hline Palm-kernel meal & 15 & I5 & I 5 & 7 & 25 & 25 \\
\hline Groundnut cake & 25 & 25 & 25 & 5 & 12 & 12 \\
\hline Blood-meal mixture & 5 & 5 & 5 & 5 & 5 & 5 \\
\hline Mineral mixture* & 3 & 3 & 3 & 3 & 3 & 3 \\
\hline
\end{tabular}

Table 3. Expt 2. Proportions in which the ingredients of the diets $(D)$ containing raw and $(E)$ boiled cassava were mixed

(Values on dry-matter basis)

\begin{tabular}{|c|c|c|c|c|c|c|c|c|}
\hline \multirow[b]{2}{*}{ Ingredient } & \multicolumn{4}{|c|}{ Period I, porkers } & \multicolumn{4}{|c|}{ Period 2, baconers } \\
\hline & $D_{\mathbf{I}}$ & $\mathrm{D}_{2}$ & $E_{\mathrm{I}}$ & $E_{2}$ & $D_{I}$ & $D_{2}$ & $E_{\mathbf{I}}$ & $E_{2}$ \\
\hline Cassava root & 42 & 42 & 42 & 42 & 60 & 60 & 60 & 60 \\
\hline Palm-kernel meal & 27 & 27 & 27 & 27 & 22 & 22 & 22 & 22 \\
\hline Groundnut cake & 28 & 28 & 28 & 28 & I3 & 13 & I3 & 13 \\
\hline Blood meal (pure) & $5 \cdot 6$ & $5 \cdot 6$ & $5 \cdot 6$ & $5 \cdot 6$ & 6 & 6 & 6 & 6 \\
\hline Mineral mixture* & $3(X)$ & $3(Y)$ & $3(X)$ & $3(Y)$ & $3(X)$ & $3(Y)$ & $3(X)$ & $3(Y)$ \\
\hline
\end{tabular}

Particulars of the diets used in Expt 2 are shown in Table 3. The cassava roots in diets $D_{1}$ and $D_{2}$ were raw, those in diets $E_{1}$ and $E_{2}$ were boiled. The moisture contents of the component parts of this diet were determined and were taken into consideration in mixing the diet in the proportions shown in Table 3 . The pure 
commercial blood meal used in Expt 2 contained $85 \%$ protein. The mineral mixture $X$ was the same as that used in Expt I, but mineral mixture $Y$ was the commercial I.C.I. iodized mineral mixture for pigs, containing: common salt $(\mathrm{NaCl}) \mathrm{I}_{4} \cdot 8$, dicalcium phosphate 14.8 , limestone flour $64^{\circ} 0$, iron 0.65 , copper 0.050 , manganese 0.115 , cobalt 0.002 , iodine $0.009 \%$.

In both experiments tap water was supplied ad lib. All pigs were given palm oil at the rate of $4 \mathrm{oz} / \mathrm{I} 6 \mathrm{lb}$ mash, equivalent to $\mathrm{I} \cdot 6 \%$ of the diet.

The amino-acid composition of the protein in the diet given in the first period in Expt $\mathrm{I}$ and in both periods in Expt 2 was assessed from the tables of Harvey (1956). The amino-acid composition of palm-kernel meal is not given in the tables; hence the amino acids from this source were not included in the assessment. The values obtained were compared with the amino-acid requirements of weanling pigs as summarized from three different sources by Evans (1958) in his table 3. This comparison showed that all the diets contained the necessary amino acids (with the exception of methionine, in which groundnuts are deficient) in sufficient amounts to support the growth of the pigs. The amount of methionine appeared to be suboptimal, even when account was taken of the quantity of cystine in the diet. This picture does not necessarily mean that the diet was deficient in methionine (and cystine) since information about the amounts of these acids contributed by the protein of palm-kernel meal was not available.

In both experiments the animals were fed thrice daily. The quantities of food given were adjusted weekly according to age, weight and appetite. After each feed the uneaten mash was collected and weighed and its weight was deducted from that of the amount given. In this way the total weight of food consumed by each animal in the experimental period was calculated.

The animals were weighed once a week before the morning feed. Period $\mathrm{I}$ ended when the pigs weighed $105 \mathrm{lb}$ in Expt $\mathrm{I}$ and $\mathrm{I} 28 \mathrm{lb}$ in Expt 2. Period 2 represents the fattening (baconer) period and was ended when the pig weighed about $200 \mathrm{lb}$.

\section{Experiment I}

The live-weight gain and efficiency of food conversion of the pigs was studied.

\section{Experiment 2}

In addition to live-weight gain and efficiency of food conversion, the metabolism of $\mathrm{N}, \mathrm{Ca}$ and $\mathrm{P}$ was studied in all the pigs during the growing and early fattening period in trials of 14 days' duration by the balance technique. The trials were begun when the animals had been io days on the cassava diet, having attained a mean live weight of $5^{2}$ or $54.5 \mathrm{lb}$. The diet was sampled and analysed weekly for its content of $\mathrm{N}, \mathrm{Ca}$ and $\mathrm{P}$. To ensure efficient collection, the faeces were collected, as they were passed, into the appropriately labelled covered bowl. The collection from each pig was weighed and thoroughly mixed each morning. A $150 \mathrm{~g}$ representative sample was then taken and dried at $80^{\circ}$ in a large air-circulating drying oven in the laboratory. At the same time a further sample of $20 \mathrm{~g}$ fresh faeces was taken for dry-matter 
determination. It was dried to constant weight at $105^{\circ}$ in the hot-air oven. A I $50 \mathrm{ml}$ representative sample of urine was taken daily for the determination of $\mathrm{N}, \mathrm{Ca}$ and $\mathrm{P}$.

$\mathrm{N}$ was determined by the Kjeldahl method. $\mathrm{Ca}$ and $\mathrm{P}$ were precipitated as the oxalate and molybdate, respectively, and determined volumetrically. Details of the methods have already been described (Oyenuga, I95 I).

\section{RESULTS}

\section{Live-weight gain}

The results are given in Table 4 (Expt I) and Table 5 (Expt 2). All the animals in both experiments gained weight satisfactorily until they had reached porker stage ( $105 \mathrm{lb}$ in Expt I and $\mathrm{I} 28 \mathrm{lb}$ in Expt 2). The pigs on the cassava diets gained weight more rapidly during this period than those on the cereal diet, there being little to choose between the diets with raw and boiled cassava at this stage of the pig's growth. The differences in live-weight gain between the animals of different groups, however,

Table 4. Expt $\mathrm{I}$. Mean values for live-weight gain, food consumption and efficiency of food conversion for each group of pigs

\begin{tabular}{|c|c|c|c|}
\hline & $A$ & $B$ & $C$ \\
\hline Duration of experiment (days) & $108 \cdot 7$ & $99 \cdot 3$ & $141^{\circ} 0$ \\
\hline Live weight attained at porker stage (lb) & 103.3 & $108 \cdot 6$ & $105 \cdot 6$ \\
\hline Live weight attained at baconer stage (lb) & $202 \cdot 0$ & $201 \cdot 0$ & $201 \cdot 6$ \\
\hline $\begin{array}{l}\text { Total live-weight gain during experimental } \\
\text { period (lb) }\end{array}$ & $149^{\circ} 0$ & 150.7 & 147.0 \\
\hline $\begin{array}{l}\text { Daily live-weight gain to porker stage } \\
\text { (between } 55 \text { and I05 lb) (lb) }\end{array}$ & 1.09 & $I \cdot 26$ & $I \cdot 2 I$ \\
\hline $\begin{array}{l}\text { Daily live-weight gain from porker to } \\
\text { baconer (105 to } 200 \mathrm{lb} \text { ) (lb) }\end{array}$ & $1 \cdot 5$ & $1 \cdot 7$ & 0.98 \\
\hline $\begin{array}{l}\text { Age at which } 200 \text { lb live weight was reached } \\
\text { (days) }\end{array}$ & $200 \cdot 0$ & $19 I \cdot 2$ & $228 \cdot 0$ \\
\hline $\begin{array}{l}\text { Time at which } 200 \mathrm{lb} \text { live weight was at- } \\
\text { tained from beginning of experiment } \\
\text { (days) }\end{array}$ & 104.7 & $95 \cdot 8$ & $122 \cdot 7$ \\
\hline $\begin{array}{l}\text { Amount of food consumed (oven-dried) } \\
\text { during porker stage }(55 \text { to I05 lb) (lb) }\end{array}$ & $203 \cdot 3$ & I77.9 & $176 \cdot 2$ \\
\hline $\begin{array}{l}\text { Amount of food consumed (oven-dried) } \\
\text { during baconer period (lb) }\end{array}$ & $54 \mathrm{I}^{\circ} \mathrm{O}$ & $4 I 7 \cdot 4$ & $606 \cdot 8$ \\
\hline $\begin{array}{l}\text { Food consumed (lb)/lb live-weight gain } \\
\text { to } 105 \mathrm{lb}\end{array}$ & $4 \cdot 4$ & $3 \cdot 4$ & 3.5 \\
\hline $\begin{array}{l}\text { Food consumed }(\mathrm{lb}) / \mathrm{lb} \text { live-weight gain } \\
\text { from }\end{array}$ & $5 \cdot 5$ & $4 \cdot 5$ & $6 \cdot 3$ \\
\hline
\end{tabular}

$A$, Guinea-corn diet; $B$, boiled-cassava diet; $C$, raw-cassava diet.

were not statistically significant, nor were they so when the weight gain was expressed as a percentage of the initial live weight. This result is in agreement with that previously obtained in a similar investigation (Oyenuga \& Opeke, 1957), except that in the previous work the raw cassava resulted in a slightly higher growth rate than the boiled. In Expt 2 of the investigation described now the weight of evidence appears to be in favour of raw cassava for young growing pigs.

The mean daily live-weight gain of the animals during the baconer stage was very low, particularly for the cassava-fed pigs $(\mathrm{I} \cdot 05 \mathrm{lb})$, being lowest for those given the 
raw-cassava diet. The animals on the boiled-cassava diet in Expt I grew somewhat faster than those on the cereal diet. The pigs on the boiled-cassava diet attained $200 \mathrm{lb}$ live weight in 96 days from the beginning of the experiment and in I9I days from birth. The pigs on the guinea-corn diet did not reach $200 \mathrm{lb}$ live weight until I05 days from the beginning of the experiment and 200 days from birth; those on the raw-cassava diet attained the same weight in 123 days from the beginning of the experiment and 228 days from birth.

Table 5. Expt 2. Individual and mean values for live-weight gain, food consumption and efficiency of food conversion of the pigs

Duration of experiment (days)

Live weight at porker stage (lb)

\begin{tabular}{|c|c|c|c|c|c|}
\hline \multicolumn{3}{|c|}{ Raw cassava } & \multicolumn{3}{|c|}{ Boiled cassava } \\
\hline$D_{\mathrm{r}}$ & $D_{2}$ & Mean & $E \mathrm{I}$ & $E_{2}$ & Mean \\
\hline I $79^{\circ} \circ$ & I $79 \cdot 0$ & $179 \cdot 0$ & $179^{\circ} 0$ & $200 \cdot 0$ & $189^{*} 5$ \\
\hline 120.0 & $137^{\circ} 0$ & $128 \cdot 5$ & I $49^{\circ} \mathrm{O}$ & 106.0 & $127 \cdot 5$ \\
\hline $212 \cdot 0$ & $230 \cdot 0$ & $22 I \cdot 0$ & $25^{8 \cdot 0}$ & $220^{\circ} 0$ & $239^{\circ} 0$ \\
\hline $176 \cdot 0$ & $184 \cdot 0$ & $180 \cdot 0$ & $2 I I \cdot 0$ & $176 \cdot 0$ & 193.5 \\
\hline I. 5 & $I \cdot 7$ & $I \cdot 6$ & $\mathrm{I} \cdot 8$ & $I \cdot 3$ & $r \cdot 55$ \\
\hline 0.94 & 0.95 & 0.945 & $I \cdot I$ & $I \cdot 2$ & I. I 5 \\
\hline $242 \cdot 0$ & $234^{\circ} 0$ & 238.0 & $206 \cdot 0$ & $263 \cdot 0$ & $234 \cdot 5$ \\
\hline $170 \cdot 0$ & $162 \cdot 0$ & 166.0 & $134^{\circ} \circ$ & $191^{\circ} 0$ & $162 \cdot 5$ \\
\hline $608 \cdot 5$ & $599 \cdot 0$ & $603 \cdot 8$ & 709.4 & 483.5 & $596 \cdot 5$ \\
\hline $\mathrm{I} \cdot 6$ & $I \cdot 4$ & $I \cdot 5$ & $I \cdot 5$ & $2 \cdot 5$ & $2 \cdot 0$ \\
\hline $5 \cdot 2$ & $5^{\cdot 1}$ & $5 \cdot 1$ & $5 \cdot I$ & $2 \cdot 9$ & $4 \cdot 0$ \\
\hline $3 \cdot 5$ & $3 \cdot 3$ & $3 \cdot 4$ & 3.4 & $2 \cdot 8$ & $3 \cdot I$ \\
\hline
\end{tabular}

Live weight attained at baconer stage (lb)

Total live weight gained during experi-

ment (lb)

Daily live-weight gain to porker stage (lb)

Daily live-weight gain from porker to

baconer stage (lb)

Age at which $200 \mathrm{Ib}$ was reached from

birth (days)

Age at which $200 \mathrm{lb}$ was attained from

beginning of experiment (days)

Amount of food (dry matter) consumed

during experimental period (lb)

Food consumed (lb)/lb live-weight gain

during porker period

Food consumed (lb)/lb live-weight gain

during baconer period

Food consumed (lb)/lb live-weight gain

for whole period

$D_{1}$ and $D_{2}$, diets with raw cassava and mineral mixtures $X$ and $Y$ (see p. 330) respectively; $E_{\mathrm{I}}$ and $E 2$, diets with boiled cassava and mineral mixtures $X$ and $Y$ respectively.

Table 6. Expts I and 2. Mean values for live weight and live-weight gain of the baconers in period 2

(All weights in $\mathrm{Ib}$ )

\begin{tabular}{|c|c|c|c|c|c|}
\hline & \multicolumn{3}{|c|}{$\begin{array}{l}\text { Expt } \mathrm{r} \text {-up to } \\
\text { I } 3^{\text {th }} \text { week }\end{array}$} & \multicolumn{2}{|c|}{$\begin{array}{l}\text { Expt 2-up to } \\
26 \text { th week }\end{array}$} \\
\hline & $A$ & $B$ & $\vec{C}$ & $D$ & $E$ \\
\hline Initial live weight & $57 \cdot 7$ & $55 \cdot 7$ & $54 \cdot 7$ & $4 I$ & $45 \cdot 5$ \\
\hline Final live weight & $179 \cdot 3$ & $195^{\circ} 7$ & $16 \pm \cdot 3$ & $22 \mathrm{I}$ & 224.0 \\
\hline Live-weight gain & $121 \cdot 6$ & 140.0 & 106. 6 & I 80 & 178.5 \\
\hline $\begin{array}{l}\text { Live-weight gain as a } \\
\text { percentage of initial }\end{array}$ & $252 \cdot 7$ & $26 I \cdot 9$ & $209 \cdot 0$ & 439 & 392 \\
\hline
\end{tabular}

percentage of initial

live weight

$A$, diet with guinea corn; $B, D$, diets with boiled cassava; $C, E$, diets with raw cassava.

Table 6 shows the mean live weight and live-weight gain of the baconers during the finishing stages. It will be observed that, whereas the animals fed on the boiled- 
cassava diet in Expt $\mathrm{I}$ had increased their initial live weight about 2.6 times, those on the raw-cassava diet had only doubled theirs. In Expt 2, however, the pigs fed on the raw-cassava diet had gained more weight at the 26 th week of experiment than those on the diet with boiled cassava.

When the cumulative live-weight gains of the baconers (Expt $r$ ) were examined by analysis of variance, the live-weight gains of the pigs on the boiled-cassava diet at the $13^{\text {th }}$ week of the experiment were found to be statistically superior at the I $\%$ level of significance to those of the pigs on the raw-cassava diet.

\section{Efficiency of food utilization}

The results are summarized in Table 4 (Expt I) and Table 5 (Expt 2). The animals differed in the amount of food they consumed. In Expt $\mathrm{I}$ the amount of food eaten was greatest $(783 \mathrm{lb})$ for the group on the raw-cassava diet, next greatest $(744 \mathrm{lb})$ for that on the guinea-corn diet and least $(595.3 \mathrm{lb})$ for that on the boiled-cassava diet. However, in terms of $\mathrm{lb}$ meal consumed per $\mathrm{lb}$ live-weight gain, the animals given cassava utilized their food more efficiently during the porker period than those on the guinea-corn diet. There was very little to choose at this stage between raw and boiled cassava from the point of view of efficiency of conversion. Expt 2, however, seemed to indicate that growing pigs utilized the food somewhat more efficiently when the cassava was raw.

During the second period, however, the pigs on the boiled-cassava diet proved the most efficient, followed by those on the guinea-corn diet. The pigs on raw cassava showed a low conversion efficiency at this stage, owing probably to the high proportion of raw cassava in the diet and also to a lower rate of live-weight gain of the baconers.

\section{Nitrogen balance}

Detailed results of individual $\mathrm{N}$ balances during the period of growth in Expt 2 are assembled in Table 7. All the pigs gained weight satisfactorily during the 14-day trial, those on the raw-cassava diet gaining rather more than those on the boiledcassava diet ( $\mathrm{I}^{\prime} 3$ as against $\mathrm{I} \cdot 2 \mathrm{lb} /$ day). The animals on the diets $D_{\mathrm{I}}$ and $D_{2}$ with mineral mixture $X$ also gained more weight than those on the diets $E_{1}$ and $E_{2}$ with the iodized I.C.I. mineral mixture $Y$. There were no appreciable differences in the amount of $\mathrm{N}$ retained daily by the two groups. Therefore boiling the cassava did not appear to lead to better retention of $\mathrm{N}$ in the growing pig. The animals given mineral mixture $X$ retained more $\mathrm{N}$ than those given mineral mixture $Y$. The amount of $\mathrm{N}$ retained by the pigs was fairly high, owing probably to the large amount in the diet. Protein digestibility was also high. More $\mathrm{N}$ was excreted in the urine than in the faeces.

\section{Calcium balance}

Details of the Ca balances of the individual pigs are summarized in Table 7 . The Ca content of the tap water was disregarded. The Ca intake of pigs on the boiledcassava diet was higher than of those on the raw-cassava diet. The animals given the boiled-cassava diet retained nearly $70 \%$ more $\mathrm{Ca}$ daily than those given the rawcassava diet. Boiling the cassava thus seemed to increase the apparent availability of 


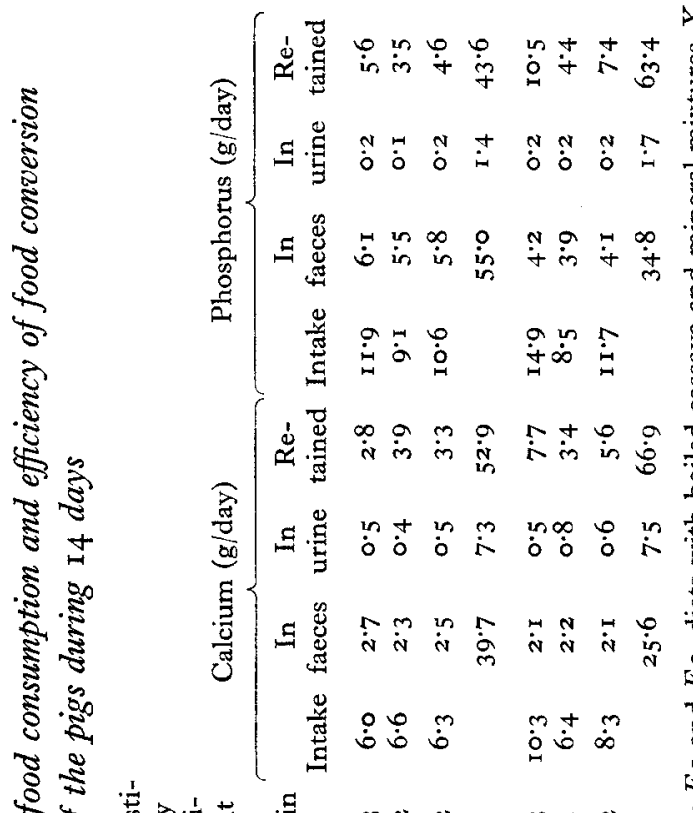

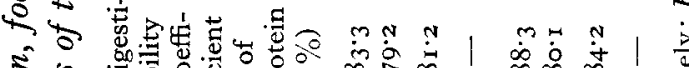

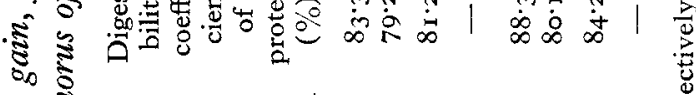

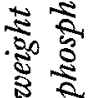

घำ

웡

s

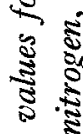

ริ ชे

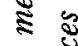

ำ

ฐ)

క్ำ

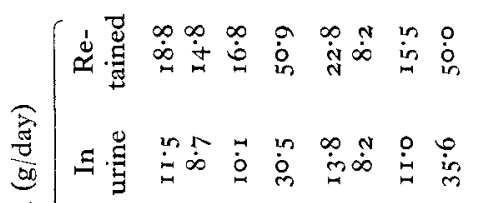

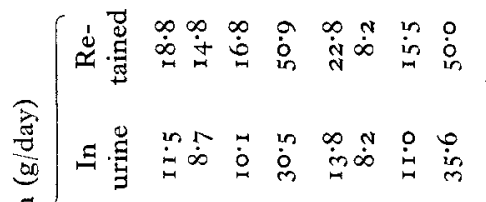

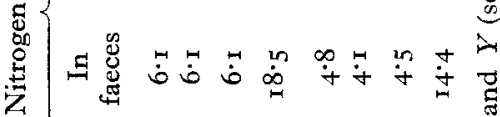

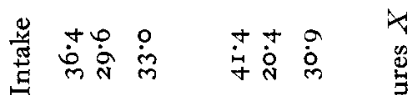

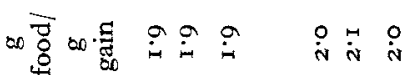

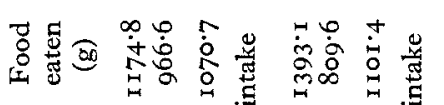

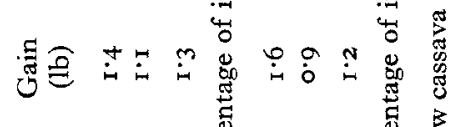

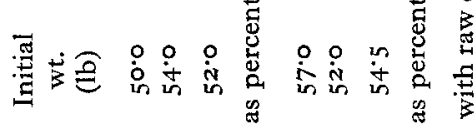

军

$\dot{1}$

है

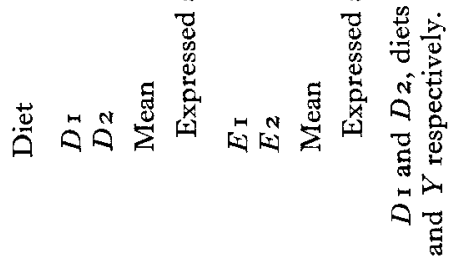


$\mathrm{Ca}$. There was no consistent difference in the intake and retention of $\mathrm{Ca}$ by the pigs on the diets containing the mineral mixtures $X$ and $Y$. The quantity of Ca retained was related to that consumed. Higher intake led to higher retention. Much more $\mathrm{Ca}$ was excreted in the faeces than in the urine.

\section{Phosphorus balance}

As with $\mathrm{Ca}$, intake and retention of $\mathrm{P}$ (Table 7 ) were higher on the diet containing boiled cassava than on that in which the cassava was raw, and the increased availability of $\mathrm{P}$ led to an increase in retention to about $60 \%$. Unlike with $\mathrm{Ca}$, however, the animals given mineral mixture $X$ retained much more $\mathrm{P}$ than those given mineral mixture $Y$, owing to the higher $\mathrm{P}$ content of the diet.

The results also confirm that faeces are the main channel for the excretion of $\mathrm{Ca}$ and $\mathrm{P}$ and that only very small quantities are excreted in the urine.

\section{DISCUSSION}

It would appear that fresh cassava root, included as the main source of carbohydrate at a level not exceeding $42 \%$ of the dry-matter content in an otherwise adequately balanced diet, is capable of supporting a satisfactory rate of weight gain in young pigs (Expt 2). Boiling the cassava has no beneficial effect for young pigs and may even lead to a slight reduction in rate of weight gain (Oyenuga \& Opeke, 1957). In Expt I, in which the cassava content of the diet was $52 \%$ of the dry-matter content, weight gain was not as rapid as in Expt 2 in which the content of the diet was $42 \%$, although it was higher than on the cereal diet. When the content of cassava in the diet was raised to $55 \%$ of the dry-matter content (period 2 of Expt $\mathrm{I}$ ), weight gain was retarded, and when cassava was included at a level of $60 \%$ it was slower still. For example, at the higher level of cassava (up to about $55 \%$ of the diet), weight gain was significantly better when the cassava was boiled. When, however, the proportion of boiled cassava in the diet was raised to $60 \%$ of the dry-matter content, weight gain was appreciably reduced. The cassava diet also appeared better utilized than the guinea-corn meal.

Generally the pigs utilized their food more efficiently during the porker than during the baconer period. It was to be expected since the maintenance requirement increases as the animal grows bigger. The pig's efficiency also declines as it grows heavier and older since at the heavier (or bacon) weight the increase in fat is greater than that in flesh or water. As the amount of energy required to lay down $\mathrm{I} \mathrm{lb}$ fat is greater than that required for $\mathrm{I} l \mathrm{lb}$ protein, it follows that the amount of energy required per unit live-weight gain would also increase. Expt 2 would also appear to show that inclusion of cassava up to a level of $60 \%$ of the diet tends to lower the animal's efficiency to convert the meal into edible carcass, particularly when the cassava is raw.

These investigations, therefore, support results previously obtained, namely that young growing pigs tend to gain weight faster on a diet containing cassava as the main source of carbohydrates than on cereal diets. The decline in the rate of weight gain that occurred in fattening pigs was due, in all probability, to the high proportion of cassava in the diet. For raw cassava root, a level of about $42 \%$ of the dry-matter 
content of the diet would seem to be about optimal for growing pigs. If the level is raised to $50 \%$ the cassava should be boiled. A level of $60 \%$, even of boiled cassava, may result in unsatisfactory weight gain.

At the $42 \%$ level a somewhat better retention of $\mathrm{N}$ (about $5 \mathrm{I} \%$ of intake) was obtained with raw cassava than with boiled (50\% of intake) (Table 7 ). The animals on the raw-cassava diet retained on average $17 \mathrm{~g} \mathrm{~N} /$ day, whereas those on the boiledcassava diet retained $\mathrm{r}_{5} \mathrm{~g} /$ day, which tends to show that the better weight gain of the pigs given raw cassava may have been due to better $\mathrm{N}$ retention. However, the digestibility coefficient for protein in the diet was greater $(84 \%)$ when the cassava was boiled than when it was raw $(8 \mathrm{I} \%)$, though the animals on the raw-cassava diet voided a smaller proportion of $\mathrm{N}$ in the urine $(30 \%)$ than those on the boiled-cassava $\operatorname{diet}(36 \%)$.

Table 8. Expt 2. Individual and mean values for calcium and phosphorus ingested per day by the pigs, expressed as a percentage of the dry-matter content of the diet, and ratios $\mathrm{Ca}: \mathrm{P}$ ingested and absorbed

\begin{tabular}{|c|c|c|c|c|c|c|}
\hline \multirow[b]{2}{*}{ Diet } & \multirow[b]{2}{*}{$\begin{array}{l}\text { Live weight } \\
\text { of pigs (lb) }\end{array}$} & \multirow[b]{2}{*}{$\begin{array}{c}\text { Daily } \\
\text { live-weight } \\
\text { gain (lb) }\end{array}$} & \multicolumn{3}{|c|}{ Ingested } & \multirow[b]{2}{*}{$\begin{array}{c}\text { Absorbed } \\
\text { Ratio, } \\
\text { Ca:P }\end{array}$} \\
\hline & & & $\mathrm{Ca}$ & $\mathbf{P}$ & $\begin{array}{l}\text { Ratio, } \\
\text { Ca:P }\end{array}$ & \\
\hline$D_{\mathbf{I}}$ & $50 \cdot 0$ & $I \cdot 4$ & 0.51 & $1 \cdot 02$ & $x: I \cdot 99$ & $I: 2.05$ \\
\hline$D_{2}$ & $54^{\circ} \circ$ & $I \cdot 3$ & 0.68 & 0.95 & I : I’39 & $1: 0.91$ \\
\hline Mean & $52 \cdot 0$ & $I \cdot 3$ & 0.59 & 0.99 & $I: I \cdot 68$ & I : I· 39 \\
\hline$E_{\text {I }}$ & $57^{\circ} \circ$ & $x \cdot 6$ & 0.74 & I.07 & $I: I \cdot 45$ & $1: 1 \cdot 35$ \\
\hline$E_{2}$ & $52 \cdot 0$ & 0.86 & 0.79 & $\mathrm{I} \cdot 05$ & $I: I \cdot 32$ & $1: 1 \cdot 27$ \\
\hline Mean & $54 \cdot 5$ & $I \cdot 2$ & 0.76 & I.06 & $I: I \cdot 40$ & $I: x \cdot 33$ \\
\hline
\end{tabular}

$D_{\mathrm{I}}$ and $D_{2}$, diets with raw cassava and mineral mixtures $X$ and $Y$ (see p. 330) respectively; $E_{\mathrm{I}}$ and $E_{2}$, diets with boiled cassava and mineral mixtures $X$ and $Y$ respectively.

The greatest advantage of boiling the cassava was its effect on the utilization and apparent digestibility of the $\mathrm{Ca}$ and $\mathrm{P}$ in the diets. The animals fed on the raw-cassava diet excreted in the faeces about $40 \%$ of the ingested $\mathrm{Ca}$, those on the boiled-cassava diet only about $25 \%$. A greater proportion of the $\mathrm{Ca}$ in the raw-cassava diet, therefore, would appear to be unavailable for absorption. As a result, only about $53 \%$ of the ingested $\mathrm{Ca}$ was retained on the raw-cassava diet and about $67 \%$ on the boiledcassava diet. Similarly, the proportion of $\mathrm{P}$ apparently unabsorbed and therefore excreted in the faeces of the pigs given the raw-cassava diet was about $55 \%$, and of those on the boiled-cassava diet it was only about $35 \%$. The proportion of the ingested $\mathrm{P}$ retained was $43.6 \%$ on the raw-cassava diet and $63.5 \%$ on the boiledcassava diet.

It is noteworthy that the $\mathrm{Ca}: \mathrm{P}$ ratios of the diets ingested or apparently absorbed (Table 8) by the two groups of pigs were not appreciably different; also the quantities ingested and apparently absorbed were adequate and there was no reason why the vitamin $\mathrm{D}$ content of the two diets should be dissimilar. Such factors, therefore, could not have been responsible for the differences obtained in the net absorption figures.

The results would seem to indicate that boiling cassava may tend to increase the 
digestibility, true and apparent, and therefore the availability to the animal, of the $\mathrm{N}$, $\mathrm{Ca}$ and $\mathrm{P}$ of the diet. It follows that the higher the proportion of raw cassava in the diet the lower will be the digestibility coefficients for these nutrients, and in all probability it is this effect that tends to lower the nutritive value of diets containing a high proportion of raw cassava and leads to low rates of weight gain of pigs fed on diets containing more than $50 \%$ raw cassava on a dry-matter basis.

The deductions, however, are complicated by the well-established fact that in all animal species faeces contain unabsorbed as well as metabolic and endogenous $\mathrm{Ca}$ and $P$, hence the amounts of these elements in the faeces are no true indication of digestibility. Maynard \& Loosli (1956) stated, however, that the distribution of Ca and P between the faeces and the urine varies with the species of animal and is to some extent influenced by such factors as age and diet. There is not much information on the channels of $\mathrm{Ca}$ and $\mathrm{P}$ excretion of the pig. It may be that this species, and under the experimental conditions described, excretes in the urine an appreciable proportion of the absorbed and already utilized $\mathrm{Ca}$ and $\mathrm{P}$. What proportion of the $\mathrm{Ca}$ and $\mathrm{P}$ found in the faeces is endogenous and metabolic is, however, not clear. Much further work on this aspect, and also on the manner in which ingestion of much raw cassava affects the availability of $\mathrm{N}, \mathrm{Ca}$ and $\mathrm{P}$ in the pig's diet, seems necessary.

\section{SUMMARY}

I. In Expt I nine home-bred pigs were fed individually in metabolic cages on well-balanced diets having as the main source of carbohydrate guinea corn in group A, boiled cassava in group $B$ and raw cassava in group $C$. Live-weight gain and efficiency of food utilization in the different groups were measured. In Expt 2 growing pigs were given a balanced diet with either raw or boiled cassava as the main source of carbohydrate. Live-weight gain and efficiency of food conversion were measured and the metabolism of nitrogen, calcium and phosphorus was studied in balance trials lasting for 14 days.

2. Gain in weight and food utilization were better on the diets containing cassava than on that with guinea corn. With young pigs, raw cassava gave somewhat better results than boiled cassava if the amount in the diet did not exceed $42 \%$ of the drymatter content, but when the level was about $50 \%$ of the dry-matter content weight gain was not satisfactory unless the cassava was boiled. Cassava, even when boiled, included as $60 \%$ of the diet resulted in unsatisfactory weight gain.

3. Raw cassava at a level of $42 \%$ of the diet also tended to lead to better retention of $\mathrm{N}$ than did boiled cassava, which in all probability accounted for the slightly better live-weight gain of the pigs given the raw-cassava diet. However, the protein of the feed was better digested when the cassava was boiled than when it was raw. The diet containing the raw cassava seemed to have led to an appreciable reduction in apparent digestibility and in the net absorption of $\mathrm{Ca}$ and $\mathrm{P}$.

4. It is suggested that the greater the quantity of cassava included in the diet the lower is the availability of the dietary $\mathrm{N}, \mathrm{Ca}$ and $\mathrm{P}$ to the pig, a fact which may be partly responsible for the poor live-weight gain of the pigs fed on a diet containing a high proportion of cassava root. 


\section{REFERENCES}

Evans, R. E. (1958). F. agric. Sci. 50, 230.

Harvey, D. (1956). Tech. Commun. Anim. Nutr., Aberd., no. I9.

Maynard, L. A. \& Loosli, J. K. (I956). Animal Nutrition, 4th ed. New York: McGraw-Hill Book Co. Oyenuga, V. A. (I95I). On the availability of manganese and iron in certain herbage species with a section on the effect of varying manurial treatment on the ash constituents of meadow hay. Ph.D. Thesis, University of Durham.

Oyenuga, V. A. (1955). Nigeria's Feeding Stuffs. Tech. Bull. no. I. Faculty of Agriculture, University College, Ibadan.

Oyenuga, V. A. \& Opeke, L. K. (1957). West Afr. F. biol. Chem. I, 3.

\section{EXPLANATION OF PLATES}

Plate I. Metabolic cage, view of inside.

Plate 2. Metabolic cage, view of outside. 
British fournal of Nutrition, Vol. I 5, No. 3

Plate I

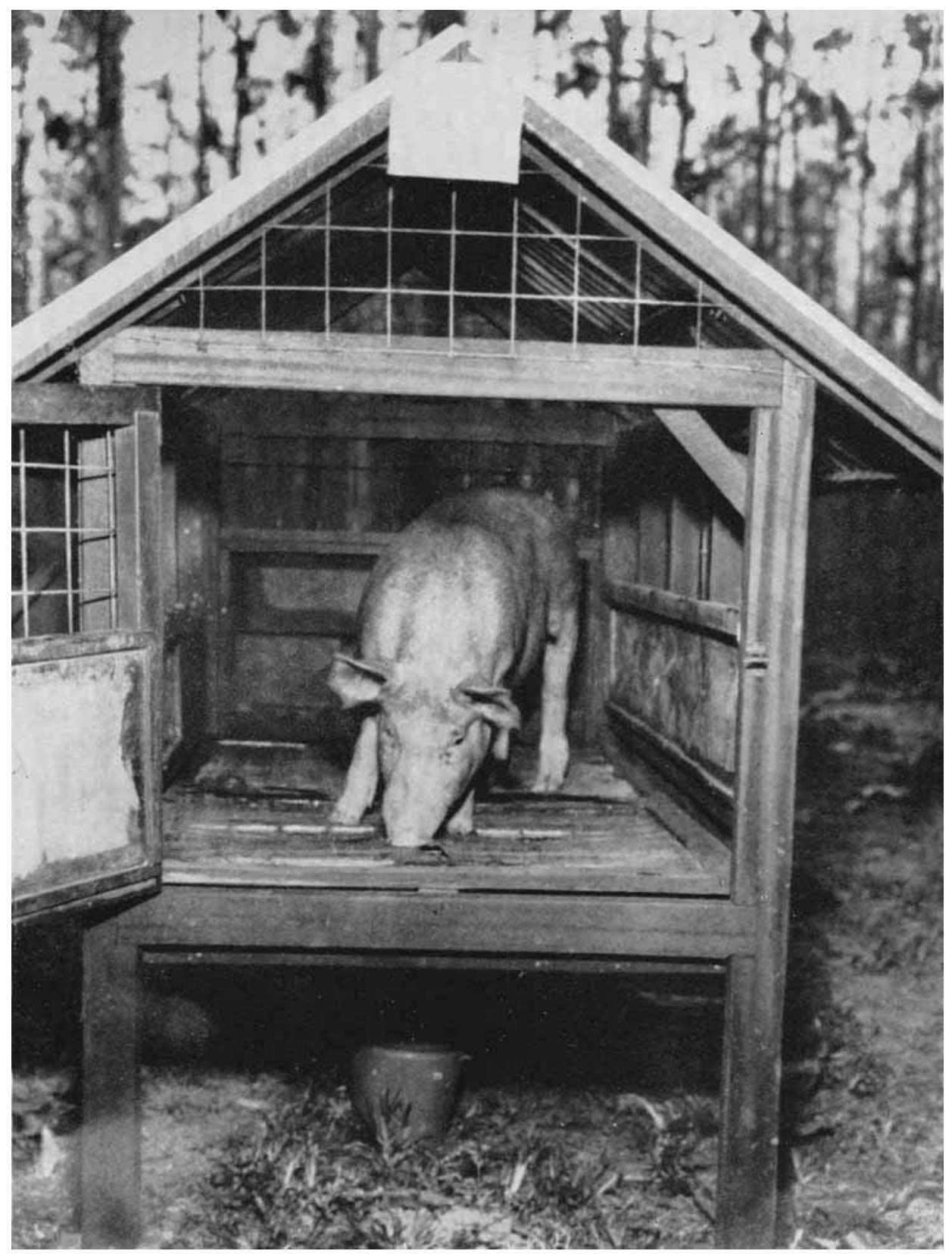

V. A. OYENUGA

(Facing p. 338) 
British Fournal of Nutrition, Vol. ${ }_{5}$, No. 3

Plate 2

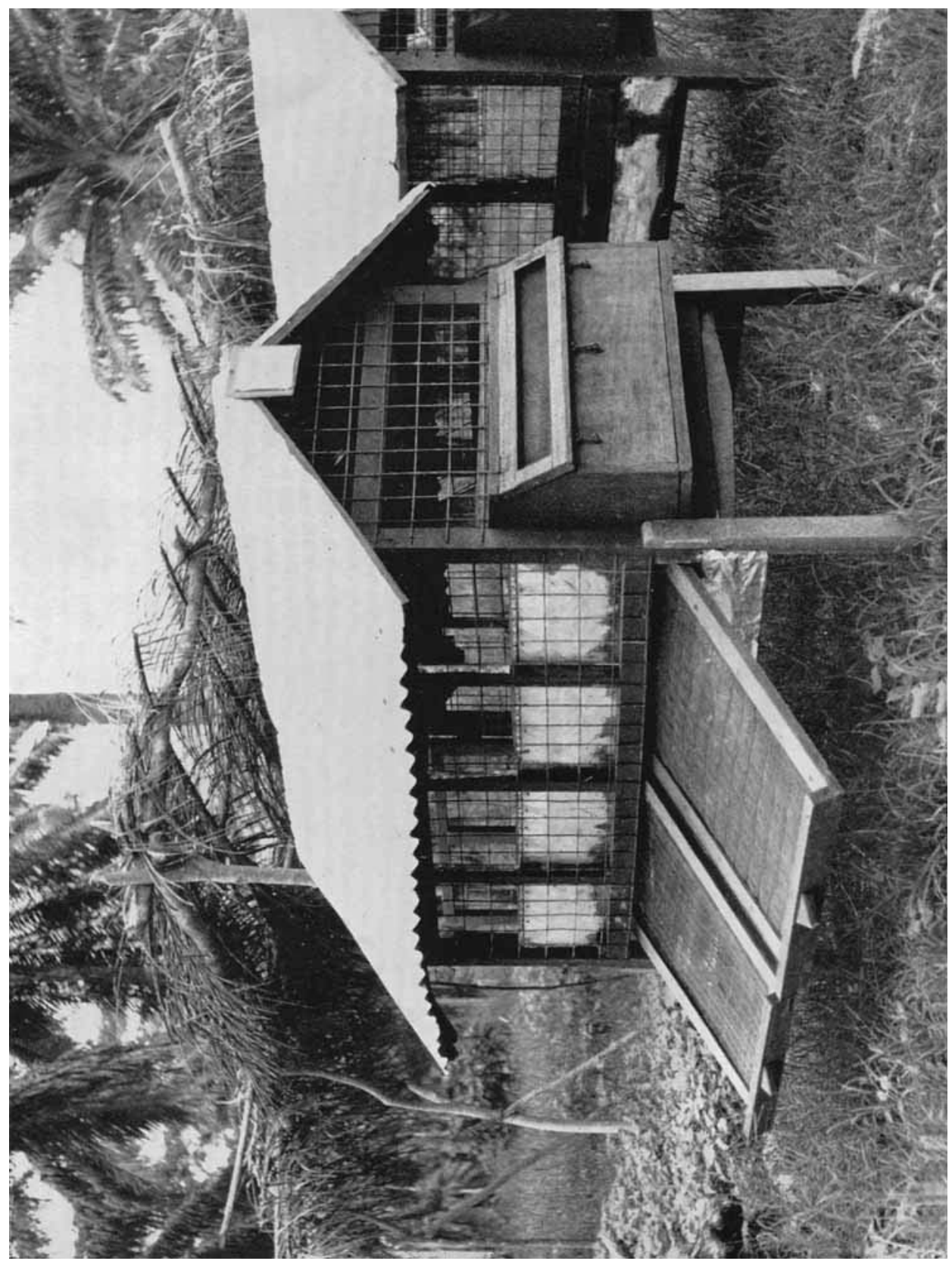

V. A. OYENUGA 